\title{
The Albanian Taxpayers' Perception of the Current Tax System and Its Impact on Informal Economy, Tax Evasion and Tax Avoidance
}

\author{
Prof. Asoc. Dr. Hysen Muceku \\ European University of Tirana \\ Email: hysen.muceku@uet.edu.al \\ Dr. Teuta Balliu \\ University of Elbasan "A.Xhuvani" \\ Email: teuta.balliu@uniel.edu.al
}

Doi:10.5901/mjss.2017.v8n1p470

\section{Abstract}

\begin{abstract}
Tax revenues constitute the main source of public expenditure financing. The main problem that the public finances in Albania are facing today is the lack of public revenue to the level that the execution of the public spending requires. This is the result of a still high level of informal economy, tax evasion and tax avoidance. The reforms undertaken by the Albanian governments in the past two decades in order to manage the main factors of the informal economy, tax evasion, and tax avoidance have not had the expected results. Poor performance of the fiscal administration agencies has allowed fiscal policies and strategies approved by governments not to be implemented, thus creating a lot of problems and difficulties with an impact on the reduction of the efficiency of the fiscal system. This paper deals with the perception of the Albanian taxpayer for the current tax system in Albania. It also deals with its impact on the informal economy, tax evasion and tax avoidance. It analyses the main factors affecting the informal economy, tax evasion and tax avoidance, and the perception that Albanian taxpayers have for the current fiscal system. A fiscal system must be effective and perceived as fair in order to encourage voluntary payment of taxes thus bringing increased revenue, reduction of informality, tax evasion and tax avoidance. In order to realize this paper we used questionnaires with focused taxpayers, explaining the techniques of collecting, interpreting and analyzing the data. The paper concludes with the main conclusions of how Albanian taxpayers perceive the current tax system. It also provides recommendations for improving the current fiscal system based on the perception of taxpayers.
\end{abstract}

Keywords: taxpayer's perception, tax system, informality, tax evasion

\section{Introduction}

In the last decade many countries have had a financial and economic crisis, where the role of the fiscal policy is essential for solving the problems which have led to this multidimensional crisis. The discussion about the impact of fiscal policy on the composition and the adjustment of the level of income, expenditure and public debt in order to achieve in time the required balance, is considered as one of the most extensive discussions in the field of public finance. In developing countries, as well as in Albania, it includes basic political issues, such as the appropriate size of the state, the government role in accelerating economic growth, social development and distribution of resources, employment growth and social welfare.

The provision and effective use of resources, especially public resources in order to achieve the policy objectives set out in economic growth and employment has an important role in the design and implementation of this policy. Various researchers emphasize that it is not only important to analyze the impact of government actions regarding the provision way and the use of proceeds, but also how these actions are perceived by the other parties involved in this process.

\section{State Role in the Real Economy}

In 1959 Musgrave has identified three basic functions of a state, the allocation, the redistribution and the stabilization (Stiglitz, 2002). Allocation occurs when the state interferes to correct the economic disorders caused by market failures. If the market does not provide adequate distribution of income and fails in this process, then it is the states task to make the 
redistribution. If the market is unstable, (for example, has high unemployment and inflation), then it is necessary the thirdline activities of the state, the stabilization one. These three main activities of the state are also known as the neoclassical role of the state. If we return once again to the above discussion, namely the information issue, on the functioning of the current government, in order to emphasize the importance of perceptions of taxpayers for the current functioning of the state, we can say that on the basis of these perceptions they do not only assess the tax system, but also the policy of a government. The fairness perception of a fiscal system, as a nationally and international discussed topic is seen as an influencing factor in predicting the taxpayers' actions. Various studies and evidences show that sometimes these perceptions are more important than even the tax rate (Baranova \& Janickova, 2012). Bordignon in his study in 1993 concluded that tax fairness has a very significant impact on the behaviour of taxpayers. It is one of the most important elements of an efficient tax system.

\section{The Connection of the Individual with the State}

The ideologies about the connection of the individual with the state affect the functioning of government in the economic sphere (Harvey \& Gayer, 2008). Political philosophers have singled out two main theories; the organic and the mechanistic point of view to the government. According to the first theory society is perceived as a natural organism. Each individual is part of this organization and the government can be thought of as his heart. The individual counts only as part of the community and the good of the individual is determined in relation to the good of the whole. As a consequence the community decides on the individual. The objectives of the society are set by the state, which leads it to their realization. It is certainly that the objective choice is varies. According to the mechanistic point of view the government is not an organic part of the society. Moreover it is a tool created by individuals in order to better achieve their individual goals. The American politician Henry Clay, in 1829 stated that: "The government is a caretaker and the officials her tutors and they are both established for the benefit of the people." At the centre is the person and not the group. Recognizing that government exists for the benefit of the people, there is still the problem of determining what is good and how should the government act to promote it. In fact there is a universal agreement that the best for individuals when government protects them from violence. In order to do so the government should have a binding monopoly because otherwise we would have anarchy. Adam Smith in his "Nations' Wealth" argues that the government should protect society from violence and from the power of other independent societies and protect as much as possible every member of its society from injustice or oppression of every another member of it (Smith, 1977). Further in the same work Smith argues that the government should be responsible for the creation and maintenance of certain public works and specific public institutions, which can never be under the interest of an only individual or a small number of individuals.

Ideology may affect the views regarding the appropriate scope of government activity. However in order to form sensitive views about public policy it is required to have more than just ideology (Boadway, Chamberlain \& Emmerson, 2009). It is also required information about the current functioning of the government. Familiarization with laws and their restrictions on the public sector is another requirement. The last requirement is to know the sources of income and ways of financing public expenditure.

The tax system is considered as very important because it is the main instrument which funds the budget of the state. An efficient tax system makes business organizations freely declare and pay their tax obligations under the laws and regulations in force.

\section{Taxpayers and Their Perceptions about the Fairness of the Tax System and Fiscal Evasion}

Taxpayers' perceptions about the fairness of the tax system, tax evasion and tax avoidance directly affects the fulfilment of the tax legislation. So taxpayers, who perceive tax evasion as dominant or that it does not constitute a significant error or crime, tend to less meet the requirements of tax legislation (Davidsson, 2012). Tax ethic is the belief that everyone must meet them in order to deliberate tax legislation requirements. It is related to the fundamental values of the taxpayer and righteousness in the distribution that represents the tax burden as compared with that of other same taxpayers. This term is known as horizontal justice or as a tax burden across different groups of taxpayers differently known as vertical justice. While the term exchanging justice is related to the evaluation of the relationship between the paid taxes and the benefits and services that the government provides citizens in response to the taxes they paid. The economic theory of the horizontal justice emphasizes that individuals with the same level of income or capital should pay the same tax obligations. Horizontal justice should be applied on individuals who are considered equal, regardless of the country's tax system. The more neutral the tax system, the more considerable should be horizontal equity (Howard, 2001). The perception of justice is very important in the public and private life of every individual. Justice, equality and social changes 
have a heavy impact on these perceptions. If individuals perceive the tax system as a fair system they will tend to support it, which is then shown by their actions. When a tax system is considered as efficient and effective? Which fiscal package makes a tax system efficient and effective? Both raised questions can be answered in different ways. Their answers depend on which country they are addressed to and the individuals of their society. This is because it is precisely those individuals who make tax evasion.

\section{Who are the Most Exposed People to the Informal Economy?}

There are a number of groups exposed to informal economy and among them the poorest groups of the labour market. The main challenge of the informal economy is still finding methods and techniques for its integration into the formal economy, as a matter of equality and social solidarity. Policies of a country should promote getting away from such economy, and the support of groups, part of this sector should be financed by the whole society. The problems that employees with labour hour's wages face are innumerable. The causes come from inadequate working codes, no job protection, problems with social security and health schemes as well as limited access to organizations protecting the rights of employees. Women as part of the informal economy continue to occupy a significant part of it. International statistics show that women occupy on average 60-80 percent of this market. Moreover, the number of labour force belonging to this group is growing, representing in this way the largest number of unpaid employees. Working girls and boys, so young people remains another major problem. They face problems and obstacles of all kinds, whose treatment and resolution requires not only attention, but also specific policies and strategies. Due to the high level of unemployment in that age group they feel obliged to address themselves to the informal sector.

Market economy obliges all businesses to operate in accordance with rules which guarantee sustainability and competitiveness. This market can be very harsh, by placing formal and informal businesses to face different obstacles that may impair business continuity. The state favourites these obstacles, not for punishing the formal business, but as measures for limiting the informal business. Such problems may be of infrastructural, institutional or economic nature (Mauro, 1995). These obstacles are connected with each other, creating in this way a vicious circle of poverty and high risk. In order to illustrate this with an example we can say that the main reasons for the lack of capital and investment opportunities for the informal sector is the inability to be financed by financial institutions (Ministry of Finance, 2014). Despite the mentioned obstacles we must emphasize that there are other factors such as product life cycle, the type of enterprise and the level of development of the society (Stiglitz, 2002).

But in this case a question arises: how much possible could be the formalization in the informal economy? The high degree of informality makes it difficult for the government to collect public revenue because the government itself must not allow informality. The efforts of the economic agents must be coordinated in the right way by the government itself, thus leading to a continuous reduction of the informal economy. The process of negotiations with the EU on the Stabilization and Association Agreement reflected the progress made by Albania during the transition period. Given that Albania has the status of a candidate country for the European Union we must say that standards and expectations have increased and not only that, but our country is now facing up even more ambitious targets. Taking into consideration the current problems with the collection of public revenue we raise the question of how to achieve these ambitious goals. The experience of developing countries has shown that improving governance in order to achieve social objectives, means passing from an economy without infrastructure to an economy which pays taxes and fees. The majority of these reforms will require reduction of corruption, bureaucratic inefficiency and other causes of the informal economy. Continuous efforts have been made towards reducing cash transactions. Banking operations and transactions only through banks and financial institutions will undoubtedly lead to an increase of informality. But not only that, even the government itself through its administrative structures can play an important role in stimulating and regulating the money movement of cash and payments. Strengthening controls of various state institutions, for identifying and denouncing the informal sector, would be other ways to formalize the informal sector. International Monetary Fund in its report of 2014 states that improving tax collection will be achieved by improving tax administration and not changing tax policy. Various studies have been made in order to measure the informal economy in Albania, so for example the OECD has estimated that the informal economy in our country is about 40 percent. The Albanian institute of statistics estimates that the weight that occupies the informal economy in our country is 32 percent.

\section{Research Methodology}

This study aims to understand how Albanians taxpayers perceive tax fairness and compliance behaviour issues. The research question of this study is: which is the perception of the Albanian taxpayers for the tax system performance. We 
will try to study this from the point of view the fairness perception over the fair value from the government in return for their income tax paid. The hypothesis constructed for the purpose of this study is: the perception over the performance of the tax system affects the taxpayer behaviour. Individual factors such as gender, age, status, level of education, and monthly income level are the independent variables of this study. The dependent variables are taxpayer's perceptions about tax fairness and tax evasion.

We constructed a questionnaire, as a way for receiving primary data, which helps us to study the taxpayer's perceptions. The questionnaires were addressed to individuals in Elbasan city who pay taxes on personal income. The questionnaire begins with some general questions, wanting in this way to identify biographical factors such as gender, age, status, level of education, and monthly income level, and it continues with a hypothetical situation. At the questionnaire we have assumed that a teacher who earns income from her job in a secondary school in the city, in her leisure time earns benefits working in handcrafts. Some questions have arisen under this situation and their purpose is the study of individuals' perceptions about tax fairness and tax evasion. The questionnaires were built as an attempt to assess the perceptions of taxpayers regarding the performance of the Albanian fiscal system. In total were distributed 200 questionnaires and we received back 150 questionnaires.

We will start with descriptive analyses, for all the data collected, after that we will use Chi-Square test with which we will try to test the connection between the demographic factors (independent variables) with the dependent variables. ANOVA test will be used as an attempt to evaluate the effect of each of the independent variables over the taxpayer's perceptions about tax fairness and tax evasion. The confidence Interval is $95 \%$ (alpha $=0.5 \%$ ). The SPSS will be used for the procession of the collected data.

\section{Results of the Analysis}

In order to realize the descriptive analysis of the selected sample we will rely on all the demographic factors taken into consider in this paper. Such factors are age, gender, marital status, education level and monthly income level. Most individuals are part of the age group of 30-39 years old (32 percent of them). The second category that follows in this age group is that of 40-49 years old. This category occupies 28 percent of the entire sample. The number of both genders taking part in this sample is of equal weight. The sample used in the study, or nearly 83 percent of it consists of married individuals and the number of family members is mostly of four (41 percent) and three members (21 percent of total). The level of education of the respondents, for most part, regards higher education. Only 25 per cent have secondary education and the other part possesses a university degree (approximately 34 percent), professional master's (22.5 percent) and Master of Science (19 percent). Its income level is mostly of 42.7 percent and coincides with the division 30000-50000 ALL and 32.6 percent in the division 50 001-100 $000 \mathrm{ALL}$.

Individuals who pay taxes on personal income do not perceive progressive tax rates as fair, nearly 41 percent said they did not at all agree that if they earn more income they will pay higher tax rates. As regarding their perception of tax evasion we can say that a significantly 59 percent of the respondents do not consider it right to declare the payment received from a second job.

Poor tax culture seems to profoundly affects not only the tendency not to declare this income, but also the feelings that arise to the taxpayers from these actions. Thus it appears that taxpayers do not feel guilty if they do not declare. They consider such income as personal sacrifice and moreover do not believe that the tax administration may detect these cases. Fully not declared incomes are largely considered as a way to gain more financial benefits. As long as these benefits are directly related to sacrificing leisure time they are considered as fair.

Table 1: Frequency table

If is fair that if I earn more income I pay higher tax rates (from $10 \%$ to $15 \%$ )

\begin{tabular}{|cc|c|c|c|c|}
\hline & & Frequency & Percent & Valid Percent & Cumulative Percent \\
\hline \multirow{4}{*}{ Valid } & Not agree at all & 61 & 40.4 & 40.4 & 40.4 \\
& Neutral & 15 & 10.1 & 10.1 & 50.6 \\
& Agree & 39 & 25.8 & 25.8 & 76.4 \\
& Agree at all & 35 & 23.6 & 23.6 & 100.0 \\
& Total & 150 & 100.0 & 100.0 & \\
\hline
\end{tabular}


I do not declare this second income because it is directly related to sacrificing my leisure time.

\begin{tabular}{|cc|c|c|c|c|}
\hline & & Frequency & Percent & Valid Percent & Cumulative Percent \\
\hline \multirow{4}{*}{ Valid } & Not agree at all & 48 & 31.5 & 31.5 & 31.5 \\
& Neutral & 45 & 30.3 & 30.3 & 61.8 \\
& Agree & 25 & 16.9 & 16.9 & 78.7 \\
& Agree at all & 32 & 21.3 & 21.3 & 100.0 \\
& Total & 150 & 100.0 & 100.0 & \\
\hline
\end{tabular}

After the descriptive analysis, we conducted the chi-square test with the data collected from this survey, this as an attempt to test the relationship between the above independent variables and the dependent variables involved.

The analysis performed shows that the level of income is the associated variable with all variables in our research, further come the education level and the age. Other demographic factors do not have strong ties to the questions raised in this part of the study.

Table 2: Chi-Square test results:

Education Level * I do not declare this second income because it is directly related to sacrificing my leisure time Chi-Square Tests

\begin{tabular}{|c|c|c|c|}
\hline & Value & df & Asymp. Sig. (2-sided) \\
\hline Pearson Chi-Square & $19.942^{\mathrm{a}}$ & 9 & .018 \\
Likelihood Ratio & 22.010 & 9 & .009 \\
Linear-by-Linear Association & .008 & 1 & .930 \\
N of Valid Cases & 139 & & \\
\hline
\end{tabular}

a. 6 cells (37.5\%) have expected count less than 5 . The minimum expected count is 2.87 .

Education Level * I would feel guilty if I won't declare the incomes earned form the second jot Chi-Square Tests

\begin{tabular}{|c|c|c|c|}
\hline & Value & $\mathrm{df}$ & Asymp. Sig. (2-sided) \\
\hline Pearson Chi-Square & $19.858^{\mathrm{a}}$ & 9 & .019 \\
Likelihood Ratio & 24.455 & 9 & .004 \\
Linear-by-Linear Association & .227 & 1 & .634 \\
N of Valid Cases & 125 & & \\
\hline
\end{tabular}

a. 7 cells (43.8\%) have expected count less than 5 . The minimum expected count is .57 .

In order to test the impact of individual factors on the perceptions of taxpayers about the vertical and horizontal fairness was used the ANOVA test as these factors represent the independent variable. In order to find out if there are significant differences for instance between different age groups and the perception of horizontal fairness of the tax system, was used the one-way ANOVA. The conducted tests for all independent variables show that the level of income and level of education have significant impacts on individuals' perceptions of the fairness of the tax system and tax evasion.

\begin{tabular}{|c|c|c|c|}
\hline \multicolumn{4}{|l|}{ ANOVA } \\
\hline & & $\mathrm{F}$ & Sig. \\
\hline I think that it is fair to declare all the personal income. & $\begin{array}{l}\text { Between Groups } \\
\text { Within Groups } \\
\text { Total }\end{array}$ & 2.322 & .064 \\
\hline It is fair that if I earn more than another person I should pay more taxes. & $\begin{array}{l}\text { Between Groups } \\
\text { Within Groups } \\
\text { Total }\end{array}$ & 10.159 & .000 \\
\hline It is fair that if I earn more income I pay higher tax rates (from $10 \%$ to $15 \%$ ) & $\begin{array}{l}\text { Between Groups } \\
\text { Within Groups } \\
\text { Total }\end{array}$ & 3.638 & .009 \\
\hline $\begin{array}{l}\text { The total amount declared to the tax administration will include even the incomes } \\
\text { from my second job. }\end{array}$ & $\begin{array}{l}\text { Between Groups } \\
\text { Within Groups } \\
\text { Total }\end{array}$ & 16.081 & .000 \\
\hline
\end{tabular}




\begin{tabular}{|c|c|c|c|}
\hline $\begin{array}{l}\text { I have no reason to declare these extra incomes and there is no reason to pay taxes } \\
\text { over them. }\end{array}$ & $\begin{array}{l}\text { Between Groups } \\
\text { Within Groups } \\
\text { Total }\end{array}$ & 5.295 & .001 \\
\hline I would not attempt to cheat by omitting to report the extra amount of $30000 \mathrm{ALL}$. & $\begin{array}{l}\text { Between Groups } \\
\text { Within Groups } \\
\text { Total }\end{array}$ & 9.456 & .000 \\
\hline $\begin{array}{l}\text { I do not declare this second income because it is directly related to sacrificing my } \\
\text { leisure time. }\end{array}$ & $\begin{array}{l}\text { Between Groups } \\
\text { Within Groups } \\
\text { Total } \\
\end{array}$ & 7.237 & .000 \\
\hline I would feel guilty if I won`t declare the incomes earned form the second jot. & $\begin{array}{l}\text { Between Groups } \\
\text { Within Groups } \\
\text { Total }\end{array}$ & 17.764 & .000 \\
\hline I would feel pleased If I did not declare the incomes from my second job. & $\begin{array}{l}\text { Between Groups } \\
\text { Within Groups } \\
\text { Total }\end{array}$ & 12.478 & .000 \\
\hline $\begin{array}{l}\text { It would be financially beneficial for me not to declare the extra amount of } 30000 \\
\text { ALL from my second job. }\end{array}$ & $\begin{array}{l}\text { Between Groups } \\
\text { Within Groups } \\
\text { Total }\end{array}$ & 7.361 & .000 \\
\hline $\begin{array}{l}\text { Tax administration has not the capacity to find out that I am earning more incomes } \\
\text { from a second job. }\end{array}$ & $\begin{array}{l}\text { Between Groups } \\
\text { Within Groups } \\
\text { Total }\end{array}$ & 2.976 & .024 \\
\hline I don't know how to declare the incomes from my second job & $\begin{array}{l}\text { Between Groups } \\
\text { Within Groups } \\
\text { Total }\end{array}$ & 2.894 & .027 \\
\hline
\end{tabular}

The last two tables show a part of the multiple comparison table used in this part of the study.

\begin{tabular}{|c|c|c|c|c|c|c|c|c|}
\hline \multirow{2}{*}{ Dependent Variable } & & \multirow{2}{*}{$\begin{array}{c}\text { (I) Monthly income } \\
\text { level }\end{array}$} & \multirow{2}{*}{$\begin{array}{c}\text { (J) Monthly income } \\
\text { level }\end{array}$} & \multirow{2}{*}{$\begin{array}{c}\text { Mean } \\
\text { Difference } \\
(\mathrm{I}-\mathrm{J})\end{array}$} & \multirow{2}{*}{$\begin{array}{l}\text { Std. } \\
\text { Error }\end{array}$} & \multirow{2}{*}{ Sig. } & \multicolumn{2}{|c|}{$\begin{array}{c}95 \% \text { Confidence } \\
\text { Interval }\end{array}$} \\
\hline & & & & & & & $\begin{array}{l}\text { Lower } \\
\text { Bound }\end{array}$ & $\begin{array}{l}\text { Upper } \\
\text { Bound }\end{array}$ \\
\hline $\begin{array}{l}\text { It is fair that if I earn more } \\
\text { than another person I should } \\
\text { pay more taxes. }\end{array}$ & $\begin{array}{l}\text { Tukey } \\
\text { HSD }\end{array}$ & above 30 000ALL & $\begin{array}{c}30001-50000 \\
50001-100000 \\
100001-150000 \\
\text { over } 150000\end{array}$ & $\begin{array}{c}.149 \\
-1.080^{*} \\
1.333 \\
-1.667\end{array}$ & $\begin{array}{l}.350 \\
.362 \\
.562 \\
.682\end{array}$ & $\begin{array}{l}.993 \\
.030 \\
.133 \\
.114\end{array}$ & $\begin{array}{c}-.83 \\
-2.09 \\
-.23 \\
-3.57\end{array}$ & $\begin{array}{c}1.12 \\
-.07 \\
2.90 \\
.23\end{array}$ \\
\hline & & $30001-50000$ & $\begin{array}{c}\text { above } 30000 \mathrm{ALL} \\
50001-100000 \\
100001-150000 \\
\text { over } 150000\end{array}$ & $\begin{array}{c}-149 \\
-1.230^{*} \\
1.184 \\
-1.816^{*}\end{array}$ & $\begin{array}{l}.350 \\
.260 \\
.502 \\
.633 \\
\end{array}$ & \begin{tabular}{l|}
.993 \\
.000 \\
.138 \\
.041
\end{tabular} & $\begin{array}{c}-1.12 \\
-1.96 \\
-.22 \\
-3.58 \\
\end{array}$ & $\begin{array}{l}.83 \\
-.50 \\
2.59 \\
-.05\end{array}$ \\
\hline & & $50001-100000$ & $\begin{array}{c}\text { above } 30 \text { 000ALL } \\
30001-50000 \\
100001-150000 \\
\text { over } 150000\end{array}$ & $\begin{array}{l}1.080^{*} \\
1.230^{*} \\
2.414^{*} \\
-.586\end{array}$ & $\begin{array}{l}.362 \\
.260 \\
.511 \\
.640\end{array}$ & $\begin{array}{l}.030 \\
.000 \\
.000 \\
.890\end{array}$ & $\begin{array}{c}.07 \\
.50 \\
.99 \\
-2.37\end{array}$ & $\begin{array}{l}2.09 \\
1.96 \\
3.84 \\
1.20 \\
\end{array}$ \\
\hline & & $100001-150000$ & $\begin{array}{c}\text { above } 30 \text { 000ALL } \\
30001-50000 \\
50001-100000 \\
\text { over } 150000\end{array}$ & $\begin{array}{l}-1.333 \\
-1.184 \\
-2.414^{*} \\
-3.000^{*}\end{array}$ & $\begin{array}{l}.562 \\
.502 \\
.511 \\
.771\end{array}$ & \begin{tabular}{l|}
.133 \\
.138 \\
.000 \\
.002
\end{tabular} & $\begin{array}{l}-2.90 \\
-2.59 \\
-3.84 \\
-5.15 \\
\end{array}$ & $\begin{array}{l}.23 \\
.22 \\
-.99 \\
-.85\end{array}$ \\
\hline & & over 150000 & $\begin{array}{c}\text { above } 30 \text { 000ALL } \\
30001-50000 \\
50001-100000 \\
100001-150000\end{array}$ & $\begin{array}{c}1.667 \\
1.816^{\star} \\
.586 \\
3.000^{\star}\end{array}$ & $\begin{array}{l}.682 \\
.633 \\
.640 \\
.771 \\
\end{array}$ & $\begin{array}{l}.114 \\
.041 \\
.890 \\
.002 \\
\end{array}$ & $\begin{array}{c}-.23 \\
.05 \\
-1.20 \\
.85\end{array}$ & $\begin{array}{l}3.57 \\
3.58 \\
2.37 \\
5.15\end{array}$ \\
\hline
\end{tabular}




\begin{tabular}{|c|c|c|c|c|c|c|c|c|}
\hline \multirow{2}{*}{ Dependent Variable } & & \multirow{2}{*}{$\begin{array}{l}\text { (I) Education } \\
\text { level }\end{array}$} & \multirow{2}{*}{$\begin{array}{l}\text { (J) Education } \\
\text { level }\end{array}$} & \multirow{2}{*}{$\begin{array}{c}\text { Mean Difference } \\
(\mathrm{I}-\mathrm{J})\end{array}$} & \multirow{2}{*}{$\begin{array}{l}\text { Std. } \\
\text { Error }\end{array}$} & \multirow{2}{*}{ Sig. } & \multicolumn{2}{|c|}{$\begin{array}{c}95 \% \text { Confidence } \\
\text { Interval }\end{array}$} \\
\hline & & & & & & & $\begin{array}{l}\text { Lower } \\
\text { Bound }\end{array}$ & $\begin{array}{l}\text { Upper } \\
\text { Bound }\end{array}$ \\
\hline \multirow[t]{4}{*}{$\begin{array}{l}\text { I would not attempt to cheat by } \\
\text { omitting to report the extra } \\
\text { amount of } 30000 \mathrm{ALL} \text {. }\end{array}$} & $\begin{array}{c}\text { Tukey } \\
\text { HSD }\end{array}$ & $\begin{array}{l}\text { secondary } \\
\text { education }\end{array}$ & $\begin{array}{l}\text { university } \\
\text { degree } \\
\text { professional } \\
\text { master } \\
\text { master of } \\
\text { Science }\end{array}$ & $\begin{array}{l}-1.067^{\star} \\
-.100 \\
-.294\end{array}$ & $\begin{array}{l}.230 \\
.253 \\
.265\end{array}$ & $\begin{array}{l}.000 \\
.979 \\
684\end{array}$ & $\begin{array}{l}-1.67 \\
-.76 \\
-.99\end{array}$ & $\begin{array}{l}-.46 \\
.56 \\
.40\end{array}$ \\
\hline & & $\begin{array}{l}\text { university } \\
\text { degree }\end{array}$ & $\begin{array}{l}\text { secondary } \\
\text { education } \\
\text { professional } \\
\text { master } \\
\text { master of } \\
\text { Science }\end{array}$ & $\begin{array}{l}1.067^{\star} \\
.967^{\star} \\
.773^{\star}\end{array}$ & $\begin{array}{l}.230 \\
.237 \\
.249\end{array}$ & $\begin{array}{l}.000 \\
.001 \\
.014\end{array}$ & $\begin{array}{l}.46 \\
.35 \\
.12\end{array}$ & $\begin{array}{l}1.67 \\
1.59 \\
1.43\end{array}$ \\
\hline & & $\begin{array}{l}\text { professional } \\
\text { master }\end{array}$ & $\begin{array}{l}\text { secondary } \\
\text { education } \\
\text { university } \\
\text { degree } \\
\text { master of } \\
\text { Science }\end{array}$ & $\begin{array}{l}.100 \\
-.967^{\star} \\
-.194\end{array}$ & $\begin{array}{l}.253 \\
.237 \\
.271\end{array}$ & $\begin{array}{l}.979 \\
.001 \\
.890\end{array}$ & $\begin{array}{l}-.56 \\
-1.59 \\
-.90\end{array}$ & $\begin{array}{l}.76 \\
-.35 \\
.52\end{array}$ \\
\hline & & $\begin{array}{l}\text { master of } \\
\text { Science }\end{array}$ & $\begin{array}{l}\text { secondary } \\
\text { education } \\
\text { university } \\
\text { degree } \\
\text { professional } \\
\text { master }\end{array}$ & $\begin{array}{c}.294 \\
-.773^{*} \\
.194\end{array}$ & $\begin{array}{l}.265 \\
.249 \\
.271\end{array}$ & $\begin{array}{l}.684 \\
.014 \\
.890\end{array}$ & $\begin{array}{l}-.40 \\
-1.43 \\
-.52\end{array}$ & $\begin{array}{l}.99 \\
-.12 \\
.90\end{array}$ \\
\hline
\end{tabular}

\section{Discussing the Results of the Paper}

The analysis performed above show the importance of the perceptions of taxpayers and the impact on their behaviour. The same as the results of other authors poor tax culture, increases the tendency for fiscal evasion, or encourages conducts that reflect income tax withholding (Torgler \& Schneider, 2004).

The perceptions of taxpayers on tax fairness also affect their behaviour towards the tax system in general. Through this study we came to the conclusion that the education level and the income level of taxpayers affect their perceptions of tax fairness. These perceptions are reflected in their behaviours towards the tax system. These results are also supported by results of other research according to which if taxpayers perceive taxes on their income as fair ones then they show positive attitudes towards taxes and the tax system. Thus the positive link between a fair tax system and the tax acceptance is made even stronger (Loo \& Mckerchar, 2010).

Progressive taxation is not perceived as fair by Albanian taxpayers and thus it increases their tendency to undeclared incomes. This connection has also been studied by researchers and other scholars and our results are confirmed by the results of their analysis and studies. These works, from which we can mention the study of Roberts, emphasize the fact that if the tax system is perceived as fair, all taxpayers declare their incomes otherwise they tend to go towards tax evasion (Roberts, 1994).

The conducted study came to the conclusion that Albanian taxpayers generally do not believe in the fairness of the current tax system. Approximately 70 percent of the respondents do not agreed that they are paying as much tax liabilities as they should. The results show that almost all respondents believe that a tax system should be built by respecting horizontal justice. Individuals who pay taxes on personal income do not perceive the progressive rates as fair. This finding provides support to (Devos, 2009).

However, beyond the results obtained, this paper has some limitations. These limitations are associated to its expansion only in the city of Elbasan in Albania. Another limitation is associated to the focusing only on individuals who pay taxes on personal incomes. The involvement of taxpayers who pay taxes on profits and capital could have further strengthened the results of this paper. 


\section{Conclusions}

Building an effective fiscal system it is important to analyze not only the impact that government actions have in the design and implementation of fiscal policy and administration of the fiscal system, but also the way how these actions are perceived by the main actors of this system the taxpayers.

Unable to fully "eliminate" informal economy, debates nowadays are focused on finding the means and methods to reduce it as much as possible and keep it at acceptable levels that do not affect economic development of the country.

In order to keep informal economy under control and at acceptable levels we should identify and analyze the factors that cause it. Several factors affect the development of this economy. These factors interact with each other leading to its growth and in some cases affecting the transition from the informal to the formal economy.

In general we can say that among the main factors affecting the growth of the informal economy, including the case of Albania may include: the degree of awareness of members of society for the fulfilment of the fiscal obligations, the approval and in many cases the "citizenship" status profit of undeclared job. Other factors are the failure of the government to take appropriate measures, as well as the malfunction in the management of the fiscal system.

In conclusion we can say that the Albanian fight against tax evasion should not only be focused on tax rates, which have been part of the recent reforms in the tax system. The implementation of laws and regulations in force as well as the non-preferential treatment of businesses are listed as other conditions and ways to reduce informality and tax evasion. Raising the society's awareness remains the duty of the authorities and the governmental institutions. Awareness may cover topics such as the uncollected taxes, ways and means by which tax and customs procedures are avoided and measures taken to avoid the created spaces. The informal economy is a widespread phenomenon, this is why every part or element of its work must be analyzed and administered separately. In the fight against it should be included all stakeholders, among which also the individuals and the registered businesses. It should also be noted that the fight against corruption is a very important part of the fight against tax evasion and informal economy. This struggle should be seen as a way of strengthening and consolidating the structures, state institutions and public administration. The tax system should be simple, widely accepted and certainly convenient to the country's economic conditions. Setting possible links between contributions and benefits of the tax system, it is seen as a good opportunity for businesses and individuals to be oriented towards the formal economy.

\section{References}

Baranova, V. \& Janickova, L. (2012). "Taxation of corporations and their impact on economic growth: The case of Eu countries". Journal of competitiveness, Vol. 4, $f, 96-108$.

Boadway R., E. Chamberlain and C. Emmerson. (2009). Taxation of Wealth and Wealth Transfers in The Mirrlees Review: Dimensions of Tax Design. . Oxford University Press.

Davidsson, M. (2012). Optimal Growth Taxation. . Research in the world economy, Vol. 3, f.35-44.

Devos, K. (2009). The attitudes of Austrialian and New Zealand tertiary students towards tax evasion. A comparative study and demographic analysis. New Zeiland Joulnal of Taxation Law and Policy 12(4) , 293-323.

Harvey S Rosen, Gayer T. (2008). Public Finance. New York, USA: Mc Graw Hill.

Howard, M. (2001). Public Sector Economics for Developing Country. . Canada: GreenWood.

Loo, E.C. \& Mckerchar, M. (2010). A pilot study on the relationship between tax fairness, enforcement, risk personality and tax compliance: The case of selected individual taxpayers. 22th Austrialian Tax Teuchers Association Conference.

Mauro, P. (1995). Corruption and Growth. . The Quarterly Journal of Economics, Vol. 110, f.25-34.

Ministry of Finance, G. o. (2014). Public Financial Management Strategy 2014-2020. Tirana, Albania: Ministry of Finance.

Roberts, M. (1994). An experimental approach to changing taxpayers' attitudes towards fairness and compliance via television. The Journal of the American Taxation Association, 16(1) , 67-86.

Smith, A. (1977). The Wealth of Nations. London: J M Dent and Sons.

Stiglitz, J. E. (2002). New Perspectives on Public Finance: recent achievements and future challenges. Journal of public Economics, NY , $125-137$.

Stiglitz, J. E. (2002). New Perspectives on Public Finance: recent achievements and future challenges. Journal of public Economics, NY. , 125-137.

Torgler, B. \& Schneider, F. (2004). does culture influence tax morale? Evidence from different Europian countries. Basel: Center for Research in Economics, Management and the Arts . 